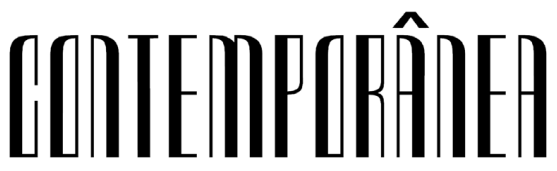

ISSN (Eletrônico): 2316-1329

http://dx.doi.org/10.4322/2316-1329.001

Contemporânea

v. 6, n. 1, p. $159-177$

Jan.-Jun. 2016

Artigo

\section{Ações penais e criminalização dos movimentos sociais de luta pela terra no Pontal do Paranapanema, SP, 1990-2014'}

\author{
Adalmir Leonidio ${ }^{2}$
}

Resumo: Este artigo busca analisar a forma como a Justiça de São Paulo tem promovido intenso processo de criminalização dos movimentos sociais de luta pela terra e, com isso, criado poderosos obstáculos à realização da reforma agrária no estado. Está baseado em uma série de ações penais movidas contra militantes do Movimento dos Trabalhadores Rurais Sem Terra (MST) na região do Pontal do Paranapanema, extremo oeste do estado. Tem por premissa central a ideia de que ao se erigir os sem terra à categoria de inimigo interno da sociedade, procede-se à minimização da política e dos direitos humanos e com isso reforça-se o avanço do Estado penal e, consequentemente, enfraquece-se a ideia do Estado social e de direitos.

Palavras-chave: ações penais; sem terras; criminalização; justiça.

Criminal actions and criminalization of social movements of struggle for land in the Pontal do Paranapanema

Abstract: This article seeks to analyze the way in which the Justice of Sao Paulo has promoted intense process of criminalisation of social movements of struggle for land and, with this, created powerful obstacles to the implementation of agrarian reform in the state. It is based on a series of penal action against militants of the Movement

\footnotetext{
${ }^{1}$ Fonte de Financiamento: Pesquisa financiada pela FAPESP.

${ }^{2}$ Departamento de Economia e Sociologia - Escola Superior de Agricultura "Luiz de Queiroz" (ESALQ) Universidade de São Paulo (USP) - Piracicaba - Brasil - leonidio@usp.br
} 
of Landless Rural Workers (MST) in the region of the Pontal do Paranapanema, in the far west of the state. Is premised on the idea that when erect the landless category of internal enemy of society, it is the minimization of political and human rights and with this reinforces the forward of the penal State and, consequently, weakens the idea of social status and rights.

Keywords: criminal actions; without land; criminality; justice.

\section{Introdução}

Apesar do avanço das lutas sociais nos centros urbanos nos últimos tempos, é sabido que os movimentos sociais de luta pela terra no Brasil, particularmente o Movimento dos Trabalhadores Rurais Sem Terra (MST), o de maior projeção nacional e internacional, vêm observando certo refluxo. Isso se deve, sem dúvida, a inúmeros fatores. Contudo, observou-se em pesquisa anterior (Leonidio, 2010) que uma das principais queixas dos sem terra em relação às dificuldades encontradas pelo movimento era justamente a atuação do Judiciário. Nesse sentido, cabe perguntar: qual tem sido o entendimento da Justiça paulista relativamente aos movimentos sociais de luta pela terra? Que tipo de protagonismo têm assumido os diferentes operadores do sistema de Justiça, particularmente os magistrados, frente a tais movimentos?

Este artigo apresenta resultados parciais de uma pesquisa em curso e tem por propósito analisar como a Justiça do Estado de São Paulo tem promovido a criminalização dos movimentos sociais de luta pela terra na região do Pontal do Paranapanema, extremo oeste do Estado. Dessa forma, busca entender como a Justiça paulista, ao invés de se constituir em um aliado da reforma agrária e da justiça social, tem se constituído no seu oposto, contribuindo para o aumento da exclusão e da marginalização social no campo.

Foram ao todo 13 ações penais analisadas, em âmbito cível e criminal, perfazendo cerca de 3 mil páginas, 15 habeas corpus e agravos de instrumento e 11 ações de reintegração/manutenção de posse, entre 1990 e 2014. A análise está dividida em duas partes, uma quantitativa - balanço das ações penais e contagem de palavras - e outra qualitativa, relativamente aos aspectos discursivos e ideológicos dos processos.

\section{Balanço das ações penais}

Das 13 ações penais analisadas, 9 foram condenatórias em primeira instância, com penas variando de 1 ano a 9 anos e seis meses de reclusão, sendo a grande maioria fixada acima do mínimo legal. Todas as sentenças foram, em geral, revertidas em segunda instância. Em dois casos houve pedido de prisão provisória, sendo mantida em segunda instância, mas retificada no Superior Tribunal de Justiça. Nas quatro ações não condenatórias, o Ministério Público pediu o arquivamento, 
Quadro 1 - Tipos de ações movidas contra o MST no Pontal do Paranapanema (SP).

\begin{tabular}{|l|c|}
\hline \multicolumn{1}{|c|}{ Tipo de ação penal } & Quantidade \\
\hline Reintegração/manutenção de posse & 12 \\
\hline Esbulho possessório & 8 \\
\hline Crimes contra a organização do trabalho & 2 \\
\hline Periclitação da vida e da saúde & 1 \\
\hline Crime de roubo/furto qualificado & 7 \\
\hline Crime contra a liberdade pessoal/cárcere privado & 1 \\
\hline Turbação da ordem & 2 \\
\hline Dano contra o patrimônio & 7 \\
\hline Formação de quadrilha e bando & 4 \\
\hline Prisão provisória & 1 \\
\hline
\end{tabular}

Fonte: Dados oriundos da pesquisa feita pelo autor nos processos analisados

seja em função da falta de provas contra a liderança, seja pela decadência do prazo para a ação.

Dos 15 habeas corpus e agravos de instrumento, nem todos referem-se aos processos acima citados, mas foram usados para avaliar a tendência dos tribunais superiores mediante esses casos. E o que se percebe com clareza é que a tendência é de os habeas corpus serem negados em segunda instância mas atendidos no Superior Tribunal de Justiça. Nota-se assim uma nítida diferença entre os juízes de comarca, em geral bastante conservadores, e os juízes dos tribunais superiores, em geral mais propensos à aplicação da Constituição e dos direitos humanos.

Tais ações penais estão divididas em vários tipos, de acordo com seu enquadramento jurídico, conforme podemos observar no Quadro 1.

Percebe-se, assim, nesse balanço quantitativo, uma série de expedientes, utilizados pela Justiça do Estado de São Paulo, com claras intenções criminalizadoras das ações do MST. Primeiramente, em relação aos mandados de reintegração/manutenção de posse, a sua quase totalidade se apresenta sob a forma de liminar. Todas foram atendidas pela Justiça, em geral no mesmo dia do pedido ${ }^{3}$. Além disso, grande parte das ações decorreram de ocupações (ou não) de fazendas que se localizam em áreas já julgadas devolutas ou que não cumprem a chamada função social da terra, conforme lista elaborada pela Comissão Pastoral da Terra (2015).

O crime de "esbulho possessório", que aparece em quase todos os processos analisados, tem sido sempre usado de forma bastante arbitrária pela magistratura. Isso porque tal delito exige, para sua configuração, a efetiva intenção de "tomar a propriedade para si”, e não como nos casos em questão, nos quais os sem terra têm por propósito pressionar o Estado para que cumpra aquilo que lhe exige a Constituição brasileira, a realização da reforma agrária.

Os casos de crime de furto são também escandalosos. O mais correto nesses casos seria dizer "saques", como nos ensina Nilo Batista (2002), pois que se trata de

\footnotetext{
${ }^{3}$ Contrariamente aos pedidos de habeas corpus, que custam a ser julgados.
} 
atender a necessidades as mais urgentes e elementares de todo ser vivo: madeira de cercas para a construção de barracos, gado e porcos para saciar a fome etc.

Há também um grande número de ações por formação de quadrilha e bando. Esse enquadramento não tem apenas o objetivo de agravar a pena, mas de dar um certo sentido ao movimento dos sem terra. Em outras palavras, ele mostra por si só o entendimento dos juízes brasileiros em relação aos sem terra e suas organizações de luta pela terra: tratam-se de organizações criminosas, voltadas para a prática de ilícitos penais e como tais devem ser penalizadas. E mais: fazer parte do movimento dos sem terra constitui crime por si mesmo. Eis o alerta dado.

Em relação aos pedidos de habeas corpus, primeiramente, há que se dizer que na maioria desses casos a prisão preventiva não se justificava, pois tratavam-se de trabalhadores rurais, com família constituída e residência fixa, não representando nenhum risco à instrução criminal ou à aplicação da lei penal. Além disso, não havia qualquer "proporcionalidade" entre a prisão preventiva decretada e o resultado possível do processo, muitos deles com penas inferiores a 2 anos e regime semiaberto. Quando se tratava da famigerada "garantia da ordem pública", o caso se tornava ainda mais escandaloso, pois significava uma verdadeira antecipação da punição, incompatível com a presunção de inocência presente em nossa Constituição. Tudo isso reafirma uma tendência no Brasil, que é o uso da prisão preventiva para fins políticos de criminalização.

Há ainda uma série de irregularidades ou nulidades jurídicas em alguns desses processos, como é o caso daquele de cárcere privado acima citado. Nesse caso, conforme vários depoimentos em fase de inquérito, os sem terra apenas tentaram impedir que um funcionário da fazenda Santa Ida, em Teodoro Sampaio, voltasse para a sede da fazenda. Isso durou cerca de meia hora, o que não configura propriamente cárcere privado.

\section{Contagem de palavras e expressões}

O que a análise dos processos em geral tem demonstrado, e que a contagem de palavras e expressões-chave vem confirmar, é que do ponto de vista da atuação dos delegados, investigadores, policiais e até promotores, atuando na fase de inquérito, a apuração de fatos não é algo decisivo para as sentenças. O que existem são convicções políticas e ideológicas, às vezes firmemente arraigadas, que norteiam as apurações, assim como as decisões dos juízes. Isto é, o juiz primeiro toma a decisão, na maior parte das vezes amparado pelas alegações finais da promotoria, mas sobretudo por suas próprias convicções e preconceitos, e só depois preocupa-se em fundamentá-la. No caso das ações contra o MST, é possível até mesmo dizer que as decisões são anteriores aos processos.

Apesar disso, continuam esses magistrados a seguir o velho princípio, profundamente ideológico, da "verdade real", na qual o juiz, não se contentando com as provas trazidas pelas partes, busca produzir ele próprio quantas provas sejam necessárias para o fim de esclarecer a "verdade dos fatos". Com isso, ele se 
torna um "juiz inquisidor", incompatível com um processo penal democrático (Pereira, 2010). Ao invés do devido processo legal, configura-se assim uma perseguição política.

Todas as palavras importantes que destacamos aqui têm relação com as ações do MST em julgamento. Após analisar atentamente os processos, mormente os relatórios finais dos delegados, alegações finais da promotoria e sentenças proferidas pelos juízes, tentamos classificar as palavras de acordo com sua área semântica ou de sentido, em um determinado contexto (Garcia, 2010). Foram ao todo cinco áreas de sentido, mas que ao se juntarem formam um sentido geral único que é a criminalização dos atos do MST. Da análise inicial resultaram cinco tabelas, que ao fim foram sintetizadas em uma única tabela, conforme observamos no Quadro 2.

Como buscarei mostrar mais à frente, uma das estratégias centrais usadas pelos operadores do sistema de justiça para criminalizar os sem terra no Estado de São Paulo e fazer refluir o movimento de ocupação de terras, é a fabricação da liderança. Isso é necessário por três razões principais. Primeiro porque o MST não é pessoa jurídica e, em sendo assim, não pode ser processado. Depois porque é simplesmente impossível responsabilizar penalmente uma massa enorme de pessoas, de identificação às vezes impraticável. Por último, porque, acredita-se, colocando os líderes na cadeia, o movimento irá naturalmente desfazer-se.

Esse intuito de fabricação da liderança fica claramente expresso quando percebemos o predomínio avassalador de palavras e expressões que denotam liderança, ao longo dos processos analisados, para se referir aos réus. Percebe-se certo silogismo nesse tipo de estratégia retórica, que acaba por criar um fato, a condenação. Como mostra o Quadro 2, foram ao todo 172 palavras da mesma área semântica, sendo algumas de forte teor pejorativo, como "manipulação", e outras, de sentido militar ou bélico, como "comando".

Como mostraremos mais à frente, em nenhum destes processos ficou provada a liderança nas supostas ações criminosas. Os réus eram responsabilizados, de forma generalizante e preconceituosa, simplesmente por serem líderes do MST em ações de ocupações de terra. É preciso lembrar que o direito penal brasileiro veda a "responsabilidade objetiva" de um crime. Artigo 29 do Código Penal: "Quem, de qualquer forma, concorre para o crime incide nas penas a este cominadas, na medida de sua culpabilidade [...]" (Brasil, 2015: 57). Assim, ao invés da presunção de inocência, a presunção de culpa. Ou, nas palavras de Raul Alfonsin, "[...] se

Quadro 2 - Palavras e expressões que aparecem nos processos e que se referem aos atos dos sem terra e suas lideranças, conforme área semântica.

\begin{tabular}{|l|c|}
\hline \multicolumn{1}{|c|}{ Área semântica } & Ocorrência \\
\hline Expressões que denotam liderança & 172 \\
\hline Expressões que denotam má personalidade do réu & 26 \\
\hline Expressões que denotam organização criminosa & 65 \\
\hline Expressões que denotam desqualificação dos réus & 189 \\
\hline Expressões que denotam estado de insegurança & 143 \\
\hline
\end{tabular}

Fonte: Dados oriundos da pesquisa feita pelo autor nos processos analisados 
não se sabia bem quem tinha praticado os alegados ilícitos, as lideranças que pagassem por isso [...]" (Alfonsin, 2014).

Esse processo de fabricação das lideranças e, consequentemente, do status de culpado conferido aos réus, recebe um poderoso aliado do próprio Direito Processual Penal, cuja teoria do "domínio dos fatos", de origem alemã, é constantemente mobilizada para fundamentar este status ${ }^{4}$. Relacionada ao tema do "concurso de pessoas", disciplinado no Código Penal, em seus artigos 29 a 31, tal teoria busca distinguir as figuras do autor e do executor, sendo autor aquele que tem 0 poder de decisão sobre a realização do fato e não só aquele que executa a "ação típica". Portanto, é considerado autor aquele que tem o controle final do fato e suas circunstâncias, geralmente o "chefe de uma quadrilha" ou o mandante de um crime, de acordo com a Lei do Crime Organizado, atualmente em vigor no Brasil (Jesus, 2001).

Mas não basta mostrar que os réus são líderes e que "pensaram", "decidiram" e "comandaram" toda a "ação criminosa", é preciso mostrar também que eles são pessoas "naturalmente" voltadas à prática de crimes ou que têm "propensão natural" para tanto. Na área semântica "Má personalidade do réu", a palavra "personalidade criminosa" aparece 8 vezes e sua congênere, também pejorativa, "malfeitores", 10 vezes. Ambas aparecem sempre associadas ao esforço dos diferentes operadores de "provarem" a liderança dos réus e de (des)qualificarem suas ações.

Essa mentalidade tem raízes no fim do século XIX, em um contexto marcado pelo fim da escravidão e pelo embaraço de nossas elites rurais e políticas, que não sabiam exatamente o que fazer com a massa de ex-escravos que vinham engrossar as fileiras de homens pobres e livres, desclassificados, marginalizados, inabsorvíveis pelo precário mercado de trabalho em ascensão, no campo ou nas cidades. Acontece que essas pessoas passaram então a compor aquilo que a literatura sociológica chama de "classes perigosas", uma ameaça à ordem constituída e à (des)organização do trabalho. Teorias como a de Cesare Lombroso, endeusadas por nossa intelectualidade tacanha da época, caíram como uma luva para justificar tal ordem de coisas. Baseados em seus aspectos físicos e em sua aparência exterior ${ }^{5}$ - de pretos e de pobres - , tais pessoas, sempre ameaçadoras, deveriam ser encarceradas, porque representavam sempre um risco ao patrimônio e à integridade de alguns poucos privilegiados dessa ordem social desigual.

Esse tipo de abordagem é reforçado pelo uso recorrente, nos autos, de antecedentes criminais dos réus. Ele tem ainda o propósito de agravar a conduta criminosa, que resulta, em caso de condenação, em aumento da pena base. $\mathrm{O}$ aumento da pena base significa que o réu não poderá gozar de certos benefícios da lei, como a prisão aberta ou domiciliar, ou até mesmo a prestação de serviços comunitários.

\footnotetext{
${ }^{4}$ Em palestra recente no Brasil, o autor da teoria, Claus Roxin (Consultor Jurídico, 2014), disse que ela tem sido usada de maneira imprópria no país.

${ }^{5}$ Note-se que as abordagens policiais no Brasil são marcadas por preconceitos dessa natureza.
} 
$\mathrm{Na}$ maioria dos processos analisados, os réus foram condenados, como visto, a mais de 4 anos de prisão e em regime fechado ou, no limite, semiaberto.

Ora, se tais pessoas têm "propensão natural" para o crime, então elas se organizam para isso, segundo a retórica desses operadores. A expressão "concorrer para" (o crime) aparece 12 vezes, "conjugar esforços para", 13 vezes e "ajustar-se para", 8 vezes. Isto é, os sem terra não se organizam "para” ocupar terras e pressionar as autoridades públicas pela realização da reforma agrária, mas "para” praticarem crimes e tirarem proveito pessoal, como inúmeras vezes ficou expresso nas alegações da promotoria. A expressão "concorrer para" tem ainda uma intenção muito clara, do ponto de vista jurídico, que é reforçar a teoria do "domínio dos fatos" ou do "concurso de pessoas".

A essa altura está claro que, para esse tipo de discurso, o MST não é um movimento social, mas uma "organização criminosa" altamente perigosa. As palavras "quadrilha/bando" aparecem 20 vezes e "organização criminosa", 17 vezes. Por sua vez, a associação entre o MST, o Primeiro Comando da Capital $(\mathrm{PCC})^{6}$ e as FARCs colombianas aparece 10 vezes. E mais uma vez aparece outra expressão de sentido militar ou bélico, a fim de referir-se a essa "organização", que é QG (Quartel General). Por fim, mas não menos importante, vem a palavra "terroristas", que aparece apenas 4 vezes.

Nesse caso, é preciso lembrar as conclusões finais da Comissão Parlamentar Mista de Inquérito da Reforma Agrária e Urbana, a CPMI da Terra. Criada em setembro de 2003, ela concluiu suas atividades em novembro de 2005 com o relatório do deputado Abelardo Lupion (PFL - PR), apresentado em substituição ao relatório original de autoria do deputado João Alfredo (PSOL - CE). Desde o início das atividades da CPMI da Terra, um dos temas que mais causou embates internos foi o da violência no campo. A partir da contestação aos dados sistematizados pela Comissão Pastoral da Terra (CPT), por ocasião do depoimento de Dom Tomás Balduino, os parlamentares ligados à Bancada Ruralista acusavam a organização de divulgar dados tendenciosos e por isso incitarem a violência. Mas foi no relatório final que o objetivo de criminalizar os movimentos sociais ficou mais explícito, pois ele ignora a ocorrência de 1,5 mil mortes no campo nos últimos 20 anos, silencia sobre a existência de trabalho escravo no país, não trata da ação de milícias armadas de pistoleiros contratados por fazendeiros, desconhece o problema da grilagem de terras e desvia o foco da concentração fundiária.

E além de pedir indiciamento de um dirigente e de um ex-dirigente da Associação Nacional de Cooperação Agrícola (ANCA) e de outro da Confederação de Cooperativas de Reforma Agrária do Brasil (CONCRAB), entidades ligadas ao MST, por desvio de recursos públicos, o texto aprovado traz, em anexo, dois projetos de lei extremamente significativos da forma como o Estado tem lidado com os conflitos no campo. Um deles visa dar conotação jurídica de ato terrorista às ocupações de terra praticadas por diversos movimentos camponeses. $\mathrm{O}$ outro propõe que o esbulho possessório (definido no texto como saque, invasão,

${ }^{6}$ Organização ligada ao tráfico de drogas na capital paulista. 
depredação ou incêndio de propriedade alheia) com fins políticos seja enquadrado como crime hediondo (Leonidio, 2010).

Podemos encontrar o mesmo intuito criminalizante no recente Projeto de Lei 499, que ainda tramita no Senado, a conhecida "Lei Antiterrorismo", que torna possível enquadrar juridicamente qualquer movimento de protesto como ato de terrorismo. No mesmo sentido vai a "Garantia da Lei e da Ordem", portaria do Ministério da Defesa que tem por finalidade "[...] estabelecer orientações para o planejamento e o emprego das Forças Armadas em Operações de Garantia da Lei e da Ordem [...]" (Brasil, 2014: 13), no âmbito daquilo que se convencionou chamar de "segurança pública".

Todas essas iniciativas do Estado remontam ou alinham-se à Lei de Segurança Nacional, "entulho jurídico da ditadura", como muitos a tem chamado, e sua ideologia do "inimigo interno ${ }^{8}$. Nos processos analisados nesta pesquisa ela nunca foi mobilizada diretamente. Mas em um processo que se arrastou por anos na Justiça Federal de Carazinho, Rio Grande do Sul, e que teve por resultado final a absolvição dos militantes acusados, ela foi usada para embasar várias acusações contra militantes do MST, entre elas: ligações com o PCC; organização de "guerrilha rural", "com o objetivo de criar uma zona de domínio, de controle através do domínio territorial, onde o MST substituiria o Estado"; tentativa de mudar o "regime vigente ou o Estado de Direito, por meios violentos ou com o emprego de grave ameaça"; "praticar atentados pessoais ou atos de terrorismo [...]"; "incitar a subversão da ordem política ou social” (Alfonsin, 2014).

Mas o núcleo ideológico da Lei de Segurança Nacional, a ideia do "inimigo interno", remonta a um período bem anterior de nossa história, imediatamente anterior e imediatamente posterior ao fim da escravidão, em que as elites rurais tremiam de medo de uma sublevação de escravos ou ex-escravos que vagavam pelos campos e pelas cidades, sem ocupação certa, a exemplo do que havia acontecido com a independência do Haiti (Bari, 2014). Sua versão atual seriam os pobres e pretos, moradores de periferia, inabsorvíveis pelo atual mercado de trabalho e excluídos das benesses do capitalismo e do consumismo.

Ora, se o MST é uma "organização criminosa", um inimigo a ser combatido pelas forças da ordem, como dizem tais operadores, suas ações são constantemente (des)qualificadas em sua própria natureza. Aqui o rol de palavras usadas é muito grande. Promovem "invasões", "destruição", "ameaças", "roubo/furto", entre outras condutas. As palavras "beligerância" e "violência", a primeira com forte sentido militar, reforçam o sentido "perigoso", "ameaçador" e "belicoso" das ações do

\footnotetext{
${ }^{7} \mathrm{Na}$ ótica do Estado brasileiro, os movimentos sociais e os problemas sociais são casos de polícia, ou, numa linguagem mais modernosa, casos de segurança pública. Trata-se de um ponto de vista ideológico que é compartilhado pela opinião pública em geral, pois sempre que sinais de "distúrbio" aparecem na imprensa, a própria população é a primeira a pedir a volta do exército às ruas.
}

8 Sobre a ideologia do “inimigo interno", ver: Arantes (2007) e Zaffaroni (2007). 
MST $^{9}$. Por seu lado, as palavras "anarquia", "torpeza" e "vandalismo" têm forte conotação pejorativa.

A palavra "invasão", usada à exaustão ao longo dos processos analisados, apesar de já ter sido bastante comentada pelos juristas brasileiros, merece aqui alguma atenção. Isso por que a "ocupação" de áreas rurais que não cumprem sua "função social", ou que são sabidamente terras devolutas, não é crime. $\mathrm{O}$ "bem jurídico propriedade" só existe enquanto bem constitucionalmente garantido (Batista, 2000). Além disso, só há "invasão de propriedade" quando há "o ânimo específico do agente de se apropriar do bem como se fosse seu" (Cintra Junior, 2002). Como dito aqui inúmeras vezes, o fim dos sem terra ao ocuparem uma fazenda não é o "esbulho possessório", mas a reforma agrária. Vista dessa forma, a ocupação é um direito de cidadania constitucionalmente garantido.

Segundo a retórica de tais operadores, o que resultaria das ações do MST no campo, para além do fato de serem criminosas? Primeiramente, segundo os processos analisados, os líderes não apenas agem conscientemente e num sentido determinado e preciso, que é a prática de crimes, eles são também desumanos, cruéis, indiferentes ao sofrimento alheio, pois "manipulam" pessoas inocentes, que agem por desespero ou boa-fé, os integrantes do MST, entre eles mulheres e crianças. Vejam nesse caso a palavra fortemente pejorativa, mais uma vez, cuja intenção é (des)qualificar as ações do MST, "massa de manobra”, que aparece 22 vezes.

Depois, resulta o estado geral de "insegurança”. A opção por incluir na análise palavras como "propriedade" e "direito" (de propriedade), ao lado de palavras como "ordem social”, "guerra civil”, "paz no campo", "desproteção", insegurança” e "medo" é porque todas elas referem-se ao sentimento dos proprietários de terra em relação às ações do MST, sentimentos esses muitas vezes usados para justificar a própria infração da lei por parte desses proprietários, como no caso em que o fazendeiro Roberto Junqueira atirou em José Rainha e depois foi inocentado pela mesma Justiça que pôs José Rainha na cadeia. Isso mostra o sentido profundamente ideológico dessas ações penais. O mesmo sentimento parece ser compartilhado pela opinião pública, expressa nos jornais de grande circulação e de claro perfil conservador do país.

Ao longo de todos os processos, a palavra Estado Democrático de Direito aparece uma única vez, exatamente para referir-se, em sentido negativo, a essas ações do MST, que com frequência violam a lei e a ordem estabelecidas, levando medo, terror e insegurança aos proprietários de terra. Ou seja, ela aparece apenas para falar dos direitos desses proprietários e de sua proteção pelo Estado, sentido profundamente liberal, mas não democrático e republicano.

\footnotetext{
9 Nesse sentido, é preciso lembrar que nas épocas mais "quentes" dos conflitos de terra no Pontal do Paranapanema, época em que o Pontal era chamado pela imprensa de "barril de pólvora", no início dos anos 1990, a Polícia Federal iniciou investigação sobre a atuação do MST, sob o pretexto de que o movimento estaria organizando uma guerrilha no campo, com o fim de alterar ou subverter a ordem constituída. Segundo depoimentos de sem terras, era comum ver-se helicópteros do Exército Brasileiro sobrevoando a região (Leonidio, 2010).
} 


\section{Aspectos ideológicos principais}

Todos os processos analisados na pesquisa têm um estilo muito parecido. Assim, a análise aqui empreendida estará baseada em apenas um dos processos, escolhido por ser o mais longo, com sentença condenatória e apelação aos tribunais superiores. Trata-se de ação de crime de periclitação da vida, dano e furto, movida pelo Ministério Público do Estado de São Paulo contra os réus José Rainha Junior, Clédson Mendes da Silva, Valmir Rodrigues Chaves e Sérgio Pantaleão, todos militantes do MST no Pontal do Paranapanema. Conforme consta nos autos do inquérito policial de número 321, nos dias 1, 2 e 3 de junho de 2000, cerca de 500 integrantes do MST teriam ocupado a fazenda Santa Ida, localizada no município de Teodoro Sampaio, e estariam sendo denunciados por supostamente terem praticado uma série de danos e furtos, bem como terem feito refém um dos funcionários da fazenda, de propriedade de Fernando Martins Antunes. Apesar da fragilidade das provas, atestada pelo próprio Tribunal de Justiça do Estado de São Paulo, em acórdão datado de 19/12/2007, os réus foram condenados a 4 anos e 8 meses de reclusão. A contradição entre uma e outra decisão é flagrante. Assim, na decisão condenatória do juiz de primeiro grau, lê-se:

Não é admissível o argumento de que os indivíduos anônimos componentes da massa agiram por si mesmo diante do grau de organização demonstrado. Finalmente, não se trataram de várias ações individuais e sim de uma única ação coletiva executada por várias pessoas sob o comando dos acusados. (São Paulo, 2000: 615).

Já na decisão do Tribunal de Justiça do Estado de São Paulo, lê-se:

Como é cediço, a invasão levada a efeito pelo movimento denominado MST, tem em mira a ocupação de fazendas tidas como improdutivas e não, evidentemente, a prática de furtos ou espoliações contra a propriedade alheia, embora isso comumente ocorra nessas circunstâncias. Assim, para que os líderes respondam por atos ilícitos da massa, mister a produção de prova induvidosa de que ordenaram ou concorreram para as subtrações, o que evidentemente não resultou cabalmente demonstrado. Por essas razões, dá-se provimento ao recurso para absolver os apelantes da acusação que lhes é feita na denúncia, com base e fundamento no artigo 386, inciso VI, do CPP. (São Paulo, 2000: 757).

Ora, o saber jurídico é um saber essencialmente retórico. Isso quer dizer que sua lógica não é a mesma dos sistemas formalizados, racionalistas e empiristas; não contém regras de construção de expressões, axiomas ou métodos de dedução. Por outro lado, sabe-se que em todos os sistemas jurídicos modernos impõe-se ao juiz a obrigação de julgar, sob a pena de ser ele acusado de denegação de justiça. Ele deve, pois, ser capaz de julgar se a lei se aplica ou não em cada caso em julgamento; e além disso, deve motivar sua sentença, ou seja, indicar como sua decisão se relaciona com a legislação por ele aplicada. Se surge alguma contradição em relação à lei a ser aplicada, o juiz terá de fazer uma escolha, bem 
como fundamentar sua escolha. Mas, se não encontrar na lei nenhum fundamento para sua decisão, deverá ainda assim ser capaz de achar uma solução. Via de regra, essa solução tem sido tomada por meio da jurisprudência. Mas poderá ser o caso de lançar mão de alguma técnica interpretativa que lhe possibilite usar alguma lei em vigor (Perelman, 1999).

Nos casos aqui analisados, o que se percebe com relativa clareza é que a decisão não aparece como um dilema perante a lei ou suas lacunas. A própria lei parece, antes, ser deduzida da experiência pessoal dos magistrados, numa técnica retórica muito parecida com aquilo que se chama "realismo jurídico" (Bobbio, 1995). Em resumo, o juiz primeiro decide no seu íntimo, de acordo com suas convicções pessoais, sua formação, sua cultura ou visão de mundo, e só depois vai buscar os fundamentos de sua decisão. Às vezes, nem isso, como no caso acima.

A decisão, em alguns casos, pode até ser bastante arbitrária. Em entrevistas realizadas na região do Pontal do Paranapanema, entre 2007 e 2008, muitos sem terra queixaram-se de que havia juízes agindo de ofício. Os casos mais comuns de queixa referiam-se às prisões provisórias. Nos processos por nós analisados, não encontramos nenhum exemplo. Mas encontramos uma outra situação, muito recorrente em mandados de reintegração de posse, cuja arbitrariedade da decisão era notória.

No processo acima referido, o proprietário, Fernando Martins Antunes, entrou com medida liminar de reintegração de posse. No mesmo dia, o juiz responsável pelo caso, Átis de Araújo Oliveira, alegando urgência, determinou que a reintegração fosse feita sem audiência prévia de conciliação, conforme preceitua o artigo 928 do Código de Processo Civil brasileiro. Contudo, e de forma ainda mais sintomática, sem que a parte assim o solicitasse, determinou que os sem terra mantivessem uma distância mínima de $10 \mathrm{~km}$ das divisas da propriedade (São Paulo, 2000: 142), violando o artigo 128 do Código de Processo Civil, que determina: "O juiz decidirá a lide nos limites em que foi proposta, sendo-lhe defeso conhecer de questões, não suscitadas, a cujo respeito a lei exige a iniciativa da parte [...]" (Brasil, 2015). Além disso, violou o artigo 5, inciso LIV, da Constituição Federal, onde se diz que “[...] ninguém será privado da liberdade ou de seus bens sem o devido processo legal", posto que restringiu a liberdade de ir e vir dos sem terra. Por fim, mostrou profunda insensibilidade em relação aos princípios éticos da Constituição, que impõe ao Estado o dever de promover o bem de todos, construindo uma sociedade mais justa e solidária.

Em seguida, o advogado do MST entrou com um pedido de reconsideração da decisão e o juiz indeferiu, apresentando três justificativas principais. Primeiramente, alegou que o pedido foi enviado via fax, mera manobra técnica que em nada desqualifica a substância do pedido. Em seguida, alega que não poderia ficar impassível "[...] diante da notória intranquilidade causada pelos integrantes do chamado MST" à propriedade invadida. Por fim, alegou que não houve violação de direitos fundamentais, uma vez que agiu no sentido de garantir o direito da outra parte, isto é, o direito de propriedade (São Paulo, 2000: 145-146). Nota-se 
assim a preeminência do direito de propriedade em relação aos demais direitos individuais.

Isto é, as decisões têm um papel fundamental no âmbito do processo, que vai muito além do fato da pena imposta aos réus. Elas conferem um sentido aos fatos em julgamento e às ações dos réus. Daí a importância do processo de conotação no uso das palavras. A conotação é o elemento instável, subjetivo da significação de uma palavra, dependente, por isso, do discurso ou contexto. Isto é, em processo conotativo, as palavras usadas sugerem ou evocam, por associação, outra ideia de ordem abstrata, de natureza afetiva ou emocional. A

[...] conotação implica, portanto, em relação à coisa designada, um estado de espírito, um julgamento, um certo grau de afetividade, que variam conforme a experiência, o temperamento, a sensibilidade, a cultura e os hábitos do falante. (Garcia, 2010).

Assim, ao invés de uma verdadeira análise do caso concreto, abundam expressões genéricas e abstratas. Ora, o predomínio do sentido conotativo nos textos processuais tem a ver, também, com um outro problema: quanto mais geral é o sentido de uma palavra, tanto mais vago e impreciso ele é. Em outras palavras, generalizações e abstrações tornam confusas as ideias, mas permitem por outro lado (ab)uso mais amplo. Isto é o que se observa nas manobras técnicas usadas amplamente por todos os operadores do direito ao longo dos processos aqui analisados.

O problema é recorrente ao longo de todo o processo, mas nos deteremos aqui apenas na tentativa de produção de provas contra as lideranças por parte da acusação, que parece ser o ponto alto de todo o processo. Isso por que o Código de Processo Penal brasileiro, em seu artigo 41, estabelece que a denúncia deve descrever de forma clara e precisa o fato criminoso, com todas as suas circunstâncias, isto é, deve individualizar a conduta supostamente realizada por cada acusado, indicando como a pessoa praticou o crime, os meios que empregou, o malefício que produziu, os motivos que a levaram a isso, a maneira como praticou, o lugar onde praticou e o tempo da ação (Pelegrini, 2001).

Inicialmente, diz a denúncia: "Os ora denunciados são líderes do MST, sendo que raramente executam materialmente os crimes [...]” (São Paulo, 2000: 2, v. 1). Primeiramente, todos sabem que o MST não tem uma organização verticalizada, de modo que não tem uma única liderança ou uma liderança central. Além disso, ainda que ele tenha algumas lideranças em uma dada região, isso não quer dizer que essas lideranças estarão à frente e serão responsáveis por todas as ações desenvolvidas na região. Em sendo assim, dizer que uma pessoa é líder do MST não imputa a essa pessoa nenhuma responsabilidade sobre uma ação específica praticada. Nessas circunstâncias, para ser precisa, a denúncia deveria indicar quem foi a liderança daquela ocupação. Além disso, dizer que as lideranças "raramente executam materialmente os crimes" é uma suposição vaga, que não precisa as condições de tempo e lugar do crime praticado. Outra suposição vaga e abstrata 
é dizer que "[...] não é possível pensar em ação do MST que seja feita à revelia da liderança” (São Paulo, 2000: 2, v. 1).

Em seguida, ainda de forma geral e abstrata, diz que "tais líderes pensam, discutem e resolvem o que fazer. São líderes de um movimento e dominam centenas de pessoas, as quais os obedecem em tudo". Para que o promotor soubesse disso e o dissesse com propriedade, teria de ter presenciado reuniões do MST e acompanhado o movimento em várias ações. Mas como não o fez, tudo o que diz não passa de suposições. Assim, ao invés de descrever o que tais lideranças e seus comandados supostamente fizeram na ação específica de ocupação da fazenda Santa Ida, perde-se em descrições generalizantes que nada provam sobre o suposto crime praticado. As palavras finais dos promotores Marcos Akira Mizuzaki e Marcelo Creste são, neste caso, exemplares:

As invasões de terra promovidas pelo MST, em regra, são acompanhadas de destruição de cercas, subtração de lascas, abate de bovinos e incêndio, de modo que a liderança, ao comandar, organizando e dirigindo centenas de pessoas para a prática de invasão de fazenda, no mínimo assumem o risco de produzirem resultados mais gravosos, como incêndios e furtos. (São Paulo, 2000: 5, v. 1).

Aqui os promotores não estão descrevendo um crime praticado, mas definindo um modus operandi do MST. Isso não é uma denúncia, mas uma profissão de fé ideológica. Sua única e explícita intenção é criminalizar as ações do MST. Na fala das próprias testemunhas de acusação, o problema repete-se, com várias contradições de tempo e lugar onde se deram os fatos, ou até mesmo em relação ao próprio autor dos fatos. Veja-se, a esse respeito, o que diz o delegado que presidiu o inquérito em seu depoimento: "Pessoas da imprensa informaram ao depoente que o réu Cledson Mendes estava no palco dos eventos" (São Paulo, 2000: 239, v. 2). Isto é, ele próprio, assim como as demais testemunhas, nada viram, nem presenciaram, mas “ouviram dizer..." E como mostrarei mais à frente, para esse "ouvir dizer" a imprensa tem um papel central.

O entendimento do juiz em sua sentença é idêntico ao da acusação, além de considerar um sofisma a ideia de "denúncia inepta" levantada pela defesa: "Os acusados são os responsáveis pelos atos dos invasores já que são os líderes da massa e a manipulam para suas práticas criminosas [...]" (São Paulo, 2000: 610, v. 3). Deve-se salientar que a "responsabilidade objetiva" de um crime não é admitida no ordenamento jurídico penal brasileiro. E foi exatamente esse o entendimento da $13^{\mathrm{a}}$ Câmara do $7^{\circ}$ Grupo da Seção Criminal do Tribunal de Justiça do Estado de São Paulo, em sessão realizada no dia 19/12/2007, cerca de dois anos após a sentença proferida pelo juiz Átis de Araújo:

A responsabilidade penal, notadamente em relação à autoria, não pode assentar-se em meras suposições, mas em concludentes elementos de convicção, a afastarem qualquer dúvida ou incerteza sobre a autoria delituosa, situação inexistente nos autos, em razão da precariedade das provas, quanto à autoria. (São Paulo, 2000: 757, v. 3, Apelação 964.164.3). 
Mas esse sentido vago e impreciso, por vezes redundante e silogístico, conferido aos textos processuais está relacionado também ao prestígio e à autoridade que se quer vincular ao falante do discurso. Para isso, há um instrumento que tem sido nos últimos tempos alvo de grande polêmica no Brasil, mas de cujo uso ninguém abre mão. Trata-se do "juridiquês", termo que designa no Brasil o uso abusivo de palavras e expressões técnicas do meio jurídico, assunto já bastante bem conhecido no Brasil: falta de clareza, precisão, concisão e até pedantismo são confundidos erudição e autoridade (Guimarães, 2012: 176).

Como mostrei em outro artigo (Leonidio, 2014), o curso de direito tem sido um dos menos refratários às mudanças. Tudo graças à nossa tradição bacharelesca. Ora, segundo o clássico Sérgio Buarque de Holanda, o exercício da inteligência, ostentado por nossos maiores talentos literários, em uma sociedade de coloração aristocrática e personalista, não significou necessariamente amor ao pensamento especulativo, instrumento de conhecimento e ação, mas decoro, distinção social, que se traduz em "amor à frase sonora, ao verbo espontâneo e abundante, à erudição ostentosa, à expressão rara” (Holanda, 1995: 75). É que, como assinala o autor, a personalidade individual, um dos traços mais marcantes de nossa cultura, herdada dos tempos coloniais, dificilmente suporta ser comandada por um sistema exigente e disciplinador. A roupagem vistosa, as palavras bonitas, a frase lapidar, os argumentos sedutores ou pensamentos inflexíveis quase sempre se impõem com força à imaginação de nossos intelectuais. A confiança no poder milagroso das ideias quase sempre se traduz num "secreto horror" à nossa realidade ${ }^{10}$.

Essa mesma mentalidade podemos notar no uso de verbos imperativos: “juntem-se aos autos", "voltem-se os autos", “CUMPRA-SE” (sempre em maiúsculas), "defiro o pedido", "expeça-se o mandado", "decreto", "condeno"... Por um lado, isso parece uma trivialidade, o discurso jurídico é um discurso da ordem, do poder constituído. Mas há aí também uma sutileza da noção de autoridade, tal como é percebida no Brasil e que só pode ser perfeitamente compreendida quando colocada no contexto da fala. Em março de 1991, parte dos sem terra que havia saído da fazenda Nova Pontal e acampado às margens da rodovia, compondo um total aproximado de 230 famílias, ocuparam a fazenda São Bento, no município de Mirante do Paranapanema. Essa foi a ocupação que contou com o maior número de despejos, 23 ao todo. Durante a primeira desocupação, 19 dias depois da entrada na fazenda, os sem terra tentaram um acordo com o governo do Estado de São Paulo, por meio da Secretaria de Justiça e Cidadania, a fim de evitar o uso da força policial. Mas o juiz Lauro Mens de Mello, da Comarca de Mirante do Paranapanema, foi intransigente. "Eu não peço, eu mando", afirmou ele, ao ser indagado sobre a solicitação do aparato policial para cumprir ordem de despejo (Folha da Tarde, 26/3/1991).

Essa postura arrogante por parte de quem exerce cargos de poder no Brasil tem a ver com certa confusão, comum entre brasileiros, entre as ideias de autoridade

\footnotetext{
${ }^{10}$ Não seria essa a razão do sucesso entre nossos magistrados de princípios fáceis como o da "verdade real"?
} 
e mando. A autoridade tem a ver com a competência funcional do agente do Estado, mas dentro dos limites da lei que regula sua atuação. Isto é, autoridade não é uma carta branca para o agente do Estado submeter tudo e todos ao seu capricho pessoal. Mando não é autoridade, é arbítrio. O problema vem de longe e tem a ver com a forma como se relacionam no país as esferas pública e privada.

Nos modernos estados europeus em formação, a esfera pública burguesa é a intermediação necessária entre a família e o Estado. No Brasil, nos domínios rurais, foi o tipo de família organizada segundo as normas clássicas do velho direito romano-canônico que prevaleceu como base e centro de toda a organização. Sempre imerso em si mesmo, não tolerando nenhuma pressão de fora, o grupo familiar manteve-se imune a qualquer restrição ou abalo. O quadro familiar tornou-se, assim, tão poderoso e exigente, que sua sombra perseguia os indivíduos mesmo fora do recinto doméstico. Nesse tipo de organização, a entidade privada confundia-se com a pública e a família colonial fornecia a ideia mais normal do poder, da respeitabilidade, da obediência e da coesão entre os homens (Holanda, 1995). O princípio individualista da organização social não predominou, portanto, nas formas de convívio, instituições e valores brasileiros.

Do ponto de vista político, essa enorme gravitação da família extensa também teve importantes consequências. Devido à dificuldade de o poder central chegar até os pontos mais distantes da colônia, as autoridades metropolitanas dependiam grandemente da colaboração do poder e do prestígio que os senhores de engenho desfrutavam localmente. Não havia uma organização pública regular e uma divisão funcional dos cargos. Muitos dos chefes de província, bem como dos ocupantes de diversos cargos da administração municipal aí chegavam graças ao clientelismo dos senhores todo poderosos. A Justiça era igualmente uma atribuição local e particularista, sujeita a toda sorte de casuísmos e à pressão dos senhores rurais poderosos. Não havia distinção entre direitos particulares da pessoa e direitos públicos. Predominava uma completa invasão do público pelo privado. Esse esquema de organização do poder e do Estado se prolongará pelo século XIX ou até mesmo, com certas nuances próprias ao novo contexto político, pelo início do século XX.

Portanto, estava ausente uma cultura que tivesse o indivíduo como centro e polo irradiador das relações sociais. $O$ indivíduo encontrava-se preso à comunidade doméstica, ao círculo familiar. O predomínio da ideia de família, de tipo patriarcal, reforçada pela presença avassaladora da escravidão, criou obstáculos à formação de uma sociedade que pudesse encarnar a ficção moderna de homens nascendo livres e iguais. Como visto, a teoria igualitária liberal recorre às leis da troca mercantil e à "identidade natural" de interesses a fim de assegurar a ordem e a satisfação geral. Na sociedade brasileira, centrada na unidade agroexportadora trabalhada por escravos, predominaram as vontades particulares que encontravam seu ambiente próprio em círculos fechados e pouco acessíveis a uma ordenação impessoal. Daí a dificuldade de desenvolvimento, entre detentores de posições públicas, de uma mentalidade que compreendesse a distinção fundamental entre público e privado. 
Além disso, a sobrevivência dos mandonismos locais com o coronelismo, e com ele o prolongamento no tempo e no espaço da corrupção, da venalidade, do nepotismo, das relações baseadas nas trocas de favores, mostra a força de uma maneira peculiar de ver a coisa pública que deita raízes nos dias de hoje, uma maneira que não distingue completamente público e privado, vendo as pessoas sempre de forma hierarquizada e sobrepondo à lei e ao interesse público as vantagens pessoais que se possa tirar em casos concretos. Assim se entende que no Brasil a autoridade esteja acima dos cidadãos, como algo distinto e à parte deles, e não como algo que exista para servi-los.

Ora, se o falante é esse cujo prestígio e autoridade estão fora de qualquer dúvida nos meios jurídicos brasileiros, quem é o outro? Em um texto já clássico, escrito no auge da ditadura brasileira, Antonio Candido mostrou que nos Estados modernos a atividade policial deve ser executada de forma implacável, "mas sem ferir demais a sensibilidade dos bem-postos na vida". Para isso, a polícia vai se misturando com a sociedade, "estabelecendo uma rede sutil de espionagem, de colaboração e delação irresponsável”. Agindo assim, ela vai progressivamente construindo a "verdade do outro para poder manipular o eu do seu paciente" (Candido, 1980: 105-106). Em suma, por meio do interrogatório, do vasculhamento do passado, da exposição das suas fraquezas, da violência física e moral, a polícia vai esculpindo o outro que se deseja.

Em um Estado de exceção nenhuma dessas sutilezas policialescas se faz necessária. A polícia, assim como o juiz, não tem necessidade de justificar os seus atos, tornando-os conforme a lei. Ela ou ele podem ser ostensivos e brutais sem terem de se justificar, pois que em um Estado de exceção é o próprio a suprimir os limites de sua atuação, a legalidade e os direitos dos cidadãos, ao menos em relação aos "mal-postos" ou aos "torturáveis" da ordem social estabelecida, como diria um outro autor (Arantes, 2007).

Esse parece ser exatamente o caso dos processos analisados. E um dos meios mais frequentes de fazê-lo é o uso recorrente de expressões que desqualificam o outro. $O$ problema já havia aparecido na contagem de palavras feita anteriormente, conforme visto. E são vários os exemplos ao longo do processo. Em alguns casos lança-se mão até mesmo de termos pejorativos, incompatíveis com o rococó linguístico dos meios jurídicos. Já no início do processo, diz o promotor Marcelo Creste em sua denúncia: "É dos autos que os caminhões utilizados para o transporte das lascas 'surrupiadas' pertencem à COCAMP [...]" (São Paulo, 2000: 5, v. 1). O mesmo termo será usado várias vezes pela principal testemunha de acusação, Fernando Martins Antunes, o proprietário da fazenda: "Na sexta-feira, 2 de junho, por volta das 9 horas, os sem terra começaram a destruir as minhas cercas, sendo que surrupiavam as madeiras [...]" (São Paulo, 2000: 31, v. 1).

A mesma estratégia de desqualificação do outro fica clara na forma de tratamento dada aos sem terra, quando comparado ao tratamento dado aos fazendeiros. Esses são tratados e descritos ao longo de todo o processo como "proprietários", "pessoas de bem", "honestos", "trabalhadores", mesmo quando se 
sabe que são eles usurpadores das terras do Estado. Os sem terra, por seu lado, são os "invasores", pessoas que "aterrorizam" o meio rural, desrespeitam as leis e levam a intranquilidade ao campo.

Vejam que esse não é o ponto de vista apenas dos operadores do sistema de justiça, mas também da opinião pública em geral. Ao longo de todos os processos analisados é recorrente o uso de notícias de jornal como meio de prova contra os sem terra. Acontece que aí não se trata só de um meio de prova, mas também de uma narrativa a ser adotada, uma forma de opinião, um certo senso comum penal que, via de regra, age por meio da desqualificação dos sem terra e suas lideranças. São sempre notícias muito tendenciosas, muitas até mentirosas, como uma do Estado de S. Paulo, de 29/8/2000, intitulada "Sem terra deixam proximidades de fazenda no Pontal", de autoria de Luiz Carlos Lopes, onde se diz que se abateram 12 cabeças de gado e que o prejuízo total foi de 80 mil reais, enquanto o próprio proprietário da fazenda, bem como o laudo técnico dizem que foram 3 cabeças de gado abatidas e que o prejuízo foi de apenas 30 mil reais. Em um outro artigo, o mesmo repórter diz:

Do outro lado da estrada, fica a fazenda Santa Ida, que também foi invadida e posteriormente desocupada. A Justiça já determinou que os acampados sejam removidos para pelo menos $10 \mathrm{~km}$ de distância da área, mas a medida ainda não foi cumprida. 'Estamos pensando em entrar naquela fazenda e quero ver o governo mobilizar o Exército para nos tirar de lá, disse José Rainha Jr. (Lopes, 2000: 7).

Ou seja, a notícia mostra o MST, tal como o fazem os operadores do sistema de Justiça, como pessoas que não respeitam as leis e as autoridades constituídas. Não é de se estranhar a indiferença nutrida entre brasileiros em relação às arbitrariedades cometidas contra os pobres e marginalizados em geral. Trata-se de um "outro nacional", para quem não valem as regras dos direitos humanos e civis, mas tão somente a rigidez do Código Penal.

\section{Considerações finais}

Fica evidente ao longo da pesquisa que no entendimento da Justiça paulista, ainda que esta opinião não seja consensual, pois, como vimos, há certa diferença entre as instâncias, os sem terra são criminosos e que o lugar deles é na cadeia. Fica clara também a forma como a Justiça tem agido para colocar essas pessoas na cadeia: por meio da perseguição às suas lideranças, ainda que para isso se atropele a própria lei. Segundo relatos de um advogado, em um ano foram 69 pedidos de prisão provisória! Não há movimento social que resista a isso. Assim, conclui-se que a magistratura tem protagonizado um poderoso obstáculo às lutas sociais no campo, em particular à luta pela reforma agrária. Ainda não tenho dados consistentes sobre isso, mas minha pesquisa já permite perceber inclusive uma certa correlação entre o recuo das ocupações de terra, a partir dos anos 2000, e o aumento do número de ações penais contra as lideranças rurais. 
Como dito, essa posição dos magistrados e da ideologia que a acompanha não é igual nos diferentes níveis da Justiça do Estado de São Paulo. Os juízes de primeira instância tendem a ser mais conservadores que os juízes de instâncias superiores, embora se reconheça que essa diferença percebida precise ser corroborada com mais pesquisas quantitativas.

\section{Referências}

ALFONSIN, Jacques Távora. Sem terra derrotam Lei de Segurança Nacional, entulho jurídico da ditadura. MST, 2014. Disponível em: <http://www.mst.org.br/node/16458>. Acesso em: 18 mar. 2015.

ARANTES, Paulo. Extinção. São Paulo, Boitempo, 2007.

BARI, Younes. O medo do escravo; sobre mentalidades no Brasil no contexto do fim da escravidão. Trabalho de Conclusão de Curso, ESALQ/USP, 2014.

BATISTA, Nilo. A Justiça que recusa o "prato feito" da imprensa. In: STROZAKE, Juvelino José (Org.). Questões agrárias: julgados, comentados e pareceres. São Paulo, Método, 2002.

BATISTA, Nilo. Ocupações do MST e propriedade, Boletim do IBCCRIM. São Paulo, n. 95, Outubro 2000.

BOBBIO, Norberto. Teoria geral do direito. São Paulo, Martins Fontes, 1995.

BRASIL. 2015. Disponível em: <http://www.jusbrasil.com.br/jurisprudencia/busca?q=A rt.+128+do+C\%C3\%B3digo+de+Processo+Civil>. Acesso em: 27 abr. 2015.

BRASIL. Ministério da Defesa. Garantia da Lei e da Ordem. Portaria Normativa n 186/ MD, de 31 de janeiro de 2014. Diário Oficial da União, Brasília, DF, 3 fev. 2014.

BRASIL. Minicódigo Saraiva: Penal, Constituição Federal e Legislação Complementar. 21. ed. São Paulo, Saraiva, 2015.

CÂNDIDO, Antonio. A verdade da repressão. In: Teresina etc. Rio de Janeiro, Paz e Terra, 1980.

CINTRA JUNIOR, Dyrceu Aguiar Dias. Função social da propriedade: esbulho possessório: domicílio. In: STROZAKE, Juvelino José (Org.). Questões agrárias: julgados, comentados e pareceres. São Paulo, Método, 2002.

COMISSÃO PASTORAL DA TERRA - CPT. 2015. Disponível em: <http://www.cptsp.com. br/terras_devolutas_do_pontal.html>.Acesso em: 13 abr. 2015.

CONSULTOR JURÍDICO - CONJUR. 2014. Disponível em: <http://www.conjur.com. br/2014-set-01/claus-roxin-critica-aplicacao-atual-teoria-dominio-fato $>$. Acesso em: 04 mar. 2015.

FOLHA DA TARDE. Juiz manda sem terra sair de área invadida. São Paulo, 26 mar. 1991.

GARCIA, Othon M. Comunicação em prosa moderna. Rio de Janeiro, FGV, 2010.

GUIMARÃES, Luciana Helena Palermo de Almeida. A simplificação da linguagem jurídica como instrumento fundamental de acesso à justiça. Revista de Ciências Humanas, 
Ciências Sociais Aplicadas, Linguagem, Letras e Artes. Ponta Grossa, n. 20, Julho/ Dezembro 2012, pp. 173-184. Disponível em: <http://www.revistas2.uepg.br/index. php/humanas>. Acesso em: 13 abr. 2015.

HOLANDA, Sérgio Buarque de. Raízes do Brasil. São Paulo, Companhia das Letras, 1995.

JESUS, Damásio. Teoria do domínio do fato no concurso de pessoas. São Paulo, Saraiva, 2001.

LEONIDIO, Adalmir. A criminalização do MST e a formação dos operadores do sistema de justiça no Brasil. Antíteses. Londrina, v. 7, n. 14, 2014.

LEONIDIO, Adalmir. Raízes da violência rural no Brasil contemporâneo. Tese de livre docência, ESALQ/USP, 2010.

LOPES, Luiz Carlos. Líder do MST adverte para levantamento no campo no Pontal. $O$ Estado de S. Paulo. São Paulo, Agosto 2000.

PELEGRINI, Ada. As nulidades no processo penal. São Paulo, Revista dos Tribunais, 2001.

PEREIRA, Marcio Ferreira Rodrigues. A tirania da verdade no processo penal brasileiro. Revista Espaço Acadêmico. Maringá, n. 115, Dezembro 2010.

PERELMAN, Chaïm. Retóricas. São Paulo, Martins Fontes, 1999.

SÃO PAULO. Poder Judiciário. Comarca de Teodoro Sampaio. Processo 321/2000. São Paulo, 2000. 3 v.

ZAFFARONI, E. Raul. O inimigo no direito penal. Rio de Janeiro, Revan, 2007.

Recebido em: 20/08/2015

Aprovado em: 15/12/2015

\section{Como citar este artigo:}

LEONIDIO, Adalmir. Ações penais e criminalização dos movimentos sociais de luta pela terra no Pontal do Paranapanema, SP, 1990-2014. Contemporânea - Revista de Sociologia da UFSCar. São Carlos. v. 6, n. 1, jan.-jun. 2016, pp. 159-177. 